\title{
KONSEP KEPALA MADRASAH DALAM MENGEMBANGKAN BUDAYA MUTU AKADEMIK RELIGIUS
}

\author{
Muhammad Husni \\ husninanang73@gmail.com \\ Muhammad Hasyim \\ hasyim@alqolam.ac.id \\ IAI Al-Qolan Gondanglegi Malang
}

\begin{abstract}
This view of the quality of education is now very diverse. Society perceives quality education is a luxury building school have, and school beautiful garden. This research method using descriptive qualitative research. The goal is to analyze and find the concept of academic quality religious culture developed by Principals. The results of the research that the concept of quality culture developed through the habit of behaving in everyday life. The findings of the research that developed the concept of quality culture is a collective agreement that puts the Islamic culture.
\end{abstract}

Keywords: Quality Culture, Academic, Religious

\section{Pendahuluan}

Pemahaman dan pandangan tentang mutu pendidikan selama ini sangat beragam. Masyarakat memandang pendidikan yang bermutu sebagai lembaga pendidikan yang megah, gedung madrasah yang kokoh dengan genting yang memerah bata, taman madrasah yang indah, dan seterusnya. Para ilmuwan memandang pendidikan bermutu sebagai madrasah yang siswanya banyak menjadi pemenang dalam berbagai lomba atau olimpiade baik di tingkat Nasional, Regional, maupun Internasional. Repatriat mempunyai pandangan yang berbeda lagi. Madrasah yang bermutu adalah madrasah yang memberikan mata pelajaran bahasa asing bagi anak-anaknya. Orang kaya tentu memiliki pandangan yang berbeda pula. Pendidikan yang bermutu adalah pendidikan yang diperoleh anaknya dengan membayar iuran yang setinggi langit untuk memperoleh berbagai paket kegiatan ekstrakurikuler. Berbagai predikat lembaga pendidikan madrasah telah lahir, seperti madrasah favorit, madrasah unggulan, madrasah plus, dan kelas unggulan. Ada pula berbagai predikat lembaga pendidikan yang juga muncul bak jamur di musim penghujan, seperti boarding school, full day school, madrasah Nasional berwawasan Internasional, madrasah 
alam, dan madrasah berwawasan internasional. Semua sebutan itu tidak lain untuk menunjukkan aspek mutu pendidikan yang bersaing di masyarakat.

Masyarakat global, masyarakat teknologi, atau masyarakat informasi yang bersifat terbuka, berubah dengan cepat dalam memberikan tuntutan, tantangan, bahkan ancaman baru. Pada abad sekarang ini, manusia berusaha mengetahui banyak (knowing much), berbuat banyak (doing much), mencapai keunggulan (being excelent), menjalin hubungan, dan bekerjasama dengan orang lain (being sociable), serta berusaha memegang teguh nilai-nilai moral (being morraly). ${ }^{1}$ Manusia unggul, bermoral, dan pekerja keras merupakan manusia yang dapat memenuhi kebutuhan dari masyarakat global, dan mampu secara tepat meraih peluang. Di sinilah, pendidikan mendapat tempat yang utama sekaligus mampu menjawab, dan menghadapi tantangan dinamika kehiduapan masyarakat karena pendidikan yang berkualitas memegang peran penting dalam peningkatan sumber daya manusia. ${ }^{2}$

Salah satu isu penting dalam penyelenggaraan pendidikan saat ini adalah mutu lulusan, dan mutu pendidikan. Dalam undang-undang nomor 20 tahun 2003 tentang sistem pendidikn Nasional pasal 4 (empat) ayat 6 (enam) juga menegaskan bahwa pendidikan diselenggarakan dengan memberdayakan semua komponen masyarakat melalui peran serta dalam penyelenggaraan, dan pengendalian mutu pendidikan. ${ }^{3} \mathrm{Akan}$ tetapi,saat ini realitas menunjukkan bahwa pendidikan menunjukkan kemerosotan dari aspek mutu baik ditingkat pendidikan dasar, menengah maupun di tingkat pendidikan tinggi. Salah satu indikator kemerosotan mutu pendidikan dibuktikan Nilai Ebtanas Murni (NEM) siswa untuk bidang studi pada jenjang pendidikan dasar, dan menengah yang tidak memperlihatkan kenaikan yang berarti bahkan dapat dikatakan konstan dari tahun ke tahun, kecuali pada beberapa madrasah dengan jumlah yang relatif kecil. $^{4} \mathrm{Hal}$ ini terjadi karena pengelolaan pendidikan yang dilakukan lebih menitikberatkan pada aspek kuantitas daripada kualitas.

${ }^{1}$ Nana Syaodih Sukmadinata, Pengendalian Mutu Pendidikan Madrasab Menengab (Bandung: PT Refik Aditama, 2006), 6.

${ }^{2}$ Umaedi, Manajemen Mutu Berbasis Madrasah (Jakarta: Direktorat Jendral Pendidikan Dasar dan Menengah Umum, 1999), 1.

${ }^{3}$ Undang-undang Republik Indonesia Nomor 20 tahun 2003 tentang Sistem Pendidikan Nasional (Yogyakarta: Pustaka Widyatama, 2003), 10.

${ }^{4}$ Umaedi, Manajemen Peningkatan (Jakarta: Direktorat Jendral Penedidikan Dasar dan Menengah Umum, 1999), 2. 
Manajemen pendidikan mutu terpadu berlandaskan pada kepuasan pelanggan sebagai sasaran utama.Pelanggan jasa pendidikan madrasah dikelompokkan menjadi dua kategori.Pertama, pelanggan internal, yaitu pengelola pendidikan, meliputi Kepala Madrasah dan pembantunya, tenaga kependidikan dan tenaga administrasi pendidikan. Kedua, pelanggan eksternal, yaitu pihak-pihak yang berkepentingan terhadap jasa layanan madrasah tetapi sifatnya tentative, yang meliputi: siswa, orang tua (wali siswa), masyarakat, dunia usaha, dan pemerintah. ${ }^{5}$ Oleh sebab itu, untuk memposisikan madrasah sebagai industri jasa, hendaknya madrasah tersebut memenuhi standar mutu, baik mutusesungguhnya (quality infact) maupun mutu persepsi (quality in percetion). Standar mutu produksi dan pelayanan diukur dengan kriteria yang sesuai dengan spesifikasi, cocok dengan pembuatan dan pengguna, tanpa cacat dan selalu memiliki kebaikan sejak awal. Mutu madrasah dalam persepsi diukur dari kepuasan pelanggan, meningkatnya minat dan harapan pelanggan.

Perubahan budaya mutu bertujuan untuk membentuk budaya yang berorientasi pada mutu, dan menjadikan mutu sebagai landasan untuk semua komponen pendidikan. Di sinilah letak pentingnya pengembangan faktor rekayasa, dan faktor motivasi, agar secara bertahap dapat dipastikan budaya mutu itu akan berkembang di dalam madrasah. Hal ini penting diterapkan bentuk-bentuk hubungan manusia yang efektif dan konstruktif agar semua anggota madrasahmerasakan adanya hubungan yang harmonis bagi terbentuknya kerjasamayang berdaya guna dan berhasil guna. Perubahan budaya pada kebudayaan mutu ini dilakukan untuk menempuh caracara, yaitu merumuskan keyakinan bersama, intervensi nilai-niai keagamaan, dan merumuskan visi dan misi madrasahsebagi salah satu institusi pendidikan formal di Indonesia.

Berdasarkan pemikiran di atas, peran Kepala Madrasah secara budaya dan birokrasi sangat penting. Oleh karena itu, penelitian ini bermaksud untuk memahami strategi Kepala Madrasah dalam mengembangkan budaya mutu, mencakup nilai, keyakinan, perilaku baik bersifat verbal maupun material di madrasah.Kepala Madrasah dalam mengembangkan budaya mutu merupakan upaya mensinergikan semua komponen madrasahagar berkomitmen pada mutu madrasah.Kepala

5Sudarwan Danin, Visi Baru Manajemen Madrasah (Jakarta: PT Bumi Angkasa, 2006), 5. 
Madrasah dalam pengembangan budaya mutu, meliputi dua unsur utama yaitu: (1) bangunan budaya (Culture Building), meliputi visi, misi, tujuan, nilai dan keyakinan, sistem penghargaan, hubungan emosional dan sosial serta desain budaya; dan (2) bangunan pribadi (Personal Building) berupa pemodelan peran, meliputi perilaku pribadi, perilaku pemimpin dan tindakan administrasi ${ }^{6}$.

\section{Kajian Teori}

\section{Konsep Kepala Madrasah}

Kepala Madrasah adalah guru yang diberi tugas tambahan untuk memimpin Raudhotul Athfal (RA), Madrasah Ibtidaiyah (MI), Madrasah Tsanawiyah (MTs), Madrasah Aliyah (MA), Madrasah Aliyah Kejuruan (MAK) yang bukan Madrasah Bertaraf Internasional (SBI) atau yang tidak dikembangkan menjadi Madrasah Bertaraf Internasional (SBI). ${ }^{7}$ Secara etimologi, Kepala Madrasah merupakan padanan dari school principal yang tugas kesehariannya menjalankan principalship atau dasar kepemimpinan. Istilah principalship mengandung makna sebagai segala sesuatu yang berkaitan dengan tugas pokok dan fungsi sebagai Kepala Madrasah.Wahjosumidjo mengartikan bahwa Kepala Madrasah adalah seorang tenaga fungsional guru yang diberi tugas untuk memimpin suatu madrasah di mana diselenggarakan proses belajar mengajar, atau tempat di mana terjadi interaksi antara guru yang memberi pelajaran dan murid yang menerima pelajaran" ${ }^{\text {. }}$

Kepala Madrasah dilukiskan sebagai orang yang memiliki harapan tinggi bagi para staf dan para siswa.Kepala Madrasah adalah mereka yang banyak mengetahui tugas-tugas mereka dan mereka yang menentukan irama bagi pengembangan madrasah.Rumusan tersebut menunjukkan pentingnya peranan Kepala Madrasah dalam menggerakkan kehidupan madrasah guna mencapai tujuan.Studi keberhasilan Kepala Madrasah menunjukkan bahwa Kepala Madrasah adalah seseorang yang menentukan titik pusat dan irama suatu madrasah.Kepala Madrasah yang berhasil adalah Kepala Madrasah yang memahami keberadaan madrasah sebagai lembaga yang kompleks dan unik, serta mampu melaksanakan perannya dalam memimpin madrasah. Jadi, Kepala Madrasah merupakan orang nomor satu dan pengendali

${ }^{6}$ Caldwell, B.J \& spink, JM,Leading The SelfManaging School(London: The Falmer press, 1992), 143.

7Permendiknas No 28 Tahun 2010

${ }^{8}$ Wahjosumijo, Kepemimpinan Kepala Madrasah, (Jakarta: Raja Grafindo Persada 1999), 83. 
segala kebijakan yang dilakukan oleh guru dan staf, memonitoring segala kegiatan di madrasah dalam kaitannya dengan budaya yang terdapat di lingkungan pendidikan.

\section{Peran dan Fungsi Kepala Madrasah}

Peran Kepala Madrasah dalam lembaga madrasah memiliki peran dominan dan menyeluruh.Mulyasa mengemukakan bahwa secara tersirat menegaskan bahwa "tugas dan tanggung jawab Kepala Madrasah menyangkut keseluruhan kegiatan madrasah".Seorang Kepala Madrasah harus mampu memobilisir sumber daya madrasah yang berkenaan dengan teknik dan administrasi pendidikan, lintas program dan lintas sektoral dengan mendayagunakan sumber-sumber yang terdapat di madrasah agar tujuan pendidikan dapat tercapai secara efektif dan efisien. Oleh karena itu, peran Kepala Madrasah sangat penting dalam peningkatan mutu pendidikan?

Sebagaimana yang diungkapkan oleh Luthfi bahwa pentingnya peran manajer dalam manajemen pendidikan sangat mempengaruhi proses pendidikan dalam mencapai tujuannya. Lembaga pendidikan yang tidak memiliki manajer diibaratkan seperti "kapal yang tidak ada nabkodanya". Artinya tidak ada orang yang mengemudikan pengelolaan lembaganya, sehingga proses pendidikan tidak bisa berjalan dengan baik $^{10}$.

Sebagaimana yang diungkapkan oleh C. Turney dan kawan-kawannya bahwa pada madrasah yang efektif itu harus memiliki pemimpin instruksional yang kuat, mempunyai fokus yang jelas terhadap lulusan, memiliki harapan yang tinggi terhadap siswa, memiliki lingkungan yang aman dan teratur, dan melakukan monitoring terhadap seluruh kegiatan yang telah tercapai. Di samping itu, setiap Kepala Madrasah juga harus menguasai seluruh aspek-aspek manajerial dan mampu mengembangkan kemampuan manajerialnya secara baik. ${ }^{11}$ Oleh karena itu, maju mundurnya kegiatan inti budaya mutu di madrasah sangat ditentukan oleh tugas dan peran Kepala Madrasah dalam mengelola madrasahnya.

\footnotetext{
${ }^{9}$ Mulyasa, E.. Menjadi Kepala Madrasah Profesional. Dalam konteks menyukseskan MBS dan KBK (Bandung: PT. Remaja Rodakarya, 2005), 182.

${ }^{10}$ Mukhtar Lutfi. Konvensi Nasional Pendidikan Indonesia II.. Manajemen Sistem Pendidikan Nasional: Sentralisasi, Dekonsentrasi dan Desentralisasi (Bandung: University Press IKIP Bandung, 1992), 161-169.

${ }^{11}$ C. Turney dkk. Op. Cit. . , 5-42.
} 
Berbicara tentang peran Kepala Madrasah, menurut Ngalim Purwanto bahwa Penelitian tentang harapan peranan Kepala Madrasah sangat penting bagi guru-guru dan murid-murid. Pada umumnya Kepala Madrasah memiliki tanggung jawab sebagai pemimpin di bidang pengajaran, pengembangan kurikulum, administrasi kesiswaan, administrasi personalia staf, hubungan masyarakat, administrasi school plant, dan perlengkapan serta budaya madrasah. Dalam memberdayakan masyarakat dan lingkungan sekitar, Kepala Madrasah merupakan kunci keberhasilan yang menaruh perhatian tentang apa yang terjadi pada peserta didik di madrasah dan apa yang dipikirkan orang tua dan masyarakat tentang madrasah. Cara kerja Kepala Madrasah dan cara ia memandang peranannya dipengaruhi oleh kepribadiannya, persiapan dan pengalaman profesionalnya, serta ketetapan yang dibuat oleh madrasah mengenai peranan Kepala Madrasah di bidang pengajaran. Pelayanan pendidikan dalam dinas bagi administrator madrasah dapat memperjelas harapan-harapan atas peranan Kepala Madrasah.

Menurut Purwanto, bahwa seorang Kepala Madrasah mempunyai sepuluh macam peranan, yaitu: sebagai pelaksana, perencana, seorang ahli, mengawasi hubungan antara anggota-anggota, mewakili kelompok, bertindak sebagai pemberi ganjaran, bertindak sebagai wasit, pemegang tanggung jawab, sebagai seorang pencipta, dan sebagai seorang ayah ${ }^{12}$. Di bawah ini terdapat sembilan fungsi Kepala Madrasah, yaitu: sebagai educator, sebagai manajer, sebagai administrator, sebagai supervisor, sebagai leader, sebagai inovator, dan sebagai motivator.

\section{Kepala Madrasah sebagai Pengembang Budaya Mutu}

Kepemimpian Kepala Madrasah pada budaya madrasah strategi baru (new) untuk memimpin lembaga madrasah yang memiliki dinamika perubahan yang tinggi dewasa ini.Pendekatan ini menjadi menarik karena budaya sebagai aktor terciptanya madrasah yang berkualitas.Kepemimpian ini menggunakan budaya mutu dalam mengarahkan madrasah untuk menciptakan budaya mutu yang kuat.Hal ini didasarkan oleh signifikasi peran pemimpin dalam membentuk dan memperkuat budaya mutu madrasah.Pemimpin dapat menggunakan peran yang lebih luas dalam mengelola madrasah secara sosial budaya.Asumsi dasar pentingnya pemimpin ini

${ }^{12}$ Ngalim Purwanto, Administrasi Dan Supervisi Pendidikan, (Bandung: PT. Remaja Rosdakarya, 2002), 65. 
adalah sebuah budaya dan terbentuk sebagai manifestasi kenyakinan, nilai, dan perilaku yang ditransformasikan oleh pemimpin untuk meningkatkan sinergitas semua komponen lembaga.Oleh karena itu, peran pemimpin dalam membangun budaya mutu sangat penting.

Menurut Schien dalam Yuki bahwa karakteristik pemimpin pada budaya mutu yaitu: (1) perhatian para peminpin mengkomunikasikan nilai-nilai, dan perhatian baik secara emosional atau dalam rapat-rapat formal kepada para anggota untuk mencapai tujuan madrasah; (2) reaksi terhadap kritis dalam lembaga; (3) pemodelan peranperan peminpin dalam mengkomunikasikan nilai-nilai dan harapan-harapan serta banyak memberi teladan secara peribadi, menunjukkan loyalitas, pengorbanan diri dan pelayanan kepada semua warga madrasah; (4) alokasi imbalan-imbalan: kriteria atau imbalan yang diberikan untuk para anggota di samping bersifat upah dan promosi, juga dilakukan melalui pujian yang bersifat formal dan informal; dan (5) kriteria menyeleksi dan memperhentikan para pemimpin dalam mempengaruhi budaya dengan merekrut kriteria anggota atau pengawai yang sesuai dengan nilai-nilai dan promosi yang dimilki lembaga. ${ }^{13}$

Menurut Sallis, peranan utama pemimpin pendidikan dalam menciptakan budaya mutu madrasah adalah: (1) memilki visi yang jelas mengenai mutu terpadu lembaganya; (2) memilki komitmen yang jelas mengenai perbaikan mutu; (3) mengomunikasikan perbaikan mutu; (4) menjamin kebutuhan pelanggan sebagai pusat kebijakan dan pekerjaan madrasah; (5) menjamin tersedianya saluran yang cukup untuk menampung suara pelanggan; (6) memimpin pengembangan staf; (7) bersikap hati-hati dan bijaksana dalam menghadapi kesalahan staf; (8) mengarahkan inovasi madrasah; (9) menjamin kejelasan struktur madrasah menengaskan tanggung jawab dan memberikan pendelegasian yang cocok dan maksimal; (10) memiliki sikap teguh untuk mengeluarkan penyimpangan dari budaya madrasah; (11) membangun budaya kelompok kerja aktif; dan (12) membangun makanisme yang sesuai untuk memantau dan menevaluasi keberhasilan ${ }^{14}$.

13Yuki, G., Leadership in Organizatioan, Kepemimpian dalam Madrasah, (Jakarta, 1991), 301-302.

${ }^{14}$ Edward Sallis. Total Quality. Manajemenin Education, 173-174 


\section{Karakteristik Kepala Madrasah yang Efektif}

Kajian-kajian karakteristik pemimpin efektif berkembang seiring dengan perkembangan dinamika madrasah.Dalam studi efektifitas orang cenderung ditemukan keragaman karakteristik pemimpin efektif.Semula pemimpin efektif identik dengan pemimpin birokrasi dan ilmiah, tetapi sekarang ditemukan strategi pemimpin baru dengan menempatkan aspek sosial budaya sebagai faktor hyang menciptakan efektifitas omadrasah.Tuntutan masyarakat terhadadap kualitas pendidikan tidak lepas dari kepemimpinan Kepala Madrasah dalam mengelola sumber daya pendidikan.Sejumlah kajian terhadap madrasah-madrasah memberi temuan tentang besarnya konstribusi Kepala Madrasah dalam menciptakan perbaikan efektivitas madrasah.

Kepala Madrasah sebagai pemimpin yang efektif sangat menentukan keberhasilan madrasah. Hal ini sesuai dengan Senat Amerika No. 359 tahun 1979 yang menetapkan bahwa madrasah yang efektif atau sukses hampir selalu ditentukan pemimpin Kepala Madrasah sebagai kunci kesuksesan. ${ }^{15}$ Kepala Madrasah tidak hanya memberi layanan saja, tetapi juga memelihara segala sesuatunya secara lancar dan terus-menerus dengan memelihara kerukunan, mencurahkan waktu, energi, intelek dan emosi untuk memperbaiki madrasah.Kepala Madrasah merupakan sosok unik membantu madrasah: berimage tentang apa yang dapat dilakukan, memberi arahan/dorongan dan keterampilan untuk membuat perkiraan image sebenarnya.

Menurut Mulyasa, kriteria pemimpin Kepala Madrasah yang efektif adalah sebagai berikut: mampu memperdayakann guru-guru untuk melaksanakan proses pembelajaran dengan baik, lancar dan produktf, dapat menjalankan tugas dan pekerjaan sesuai dengan waktu yang telah ditetapkan, mampu menjalin hubungan yang harmonis dengan masyarakat, sehingga dapat melibatkan mereka secara aktif dalam rangka mewujudkan tujuan madrsah dan pendidikan, berhasil menerapkan prinsip pemimpin yang sesuai dengan tingkat kedewasaan guru dan pegawai lain di madrasah, mampu bekerja dengan tim manajemen madrasah, dan berhasil

${ }^{15}$ Lipham J.M., Rankin R.E. \& Hoech J.A., The Principal Concept, Competencies and Cases (New York: Longman Inc 1985), 35. 
mewujudkan tujuan madrasah secara produktif sesuai dengan ketentuan yang telah ditentukan. $^{16}$

Madrasah-madrasah yang dinamakan sebagai wadah dapat diidentifikasi ke dalam 8 (delapan) karakteristik meliputi: kelemahan Kepala Madrasah dalam memimpin lembaga, bangunan kotor tidak diperbaiki dan lingkungan tidak sehat untuk belajar sehingga dapat mengganggu pertumbuhan anak, madrasah yang kekurangan tenaga/staf dan Sarana dan Prasarana, semangat kerja guru dan murid sangat rendah, pengawasan terlalu ketat sehingga guru dan staf bekerja dengan perasaan takut, program pengajaran bersifat ritualistik dan tradisional yang tidak berkaitan dengan kebutuhan murid, suasana yang kurang kondusif dan bersemangat, dan kepala Madrasah hanya menggunakan waktu sekedarnya untuk mereka (serving out their time).

\section{Konsep Budaya Mutu}

Dalam Kamus Besar Bahasa Indonesia, budaya (cultural) diartikan sebagai: pikiran; adat istiadat; suatu yang sudah berkembang; sesuatu yang menjadi kebiasaan yang sukar diubah ${ }^{17}$. Dalam pemakaian sehari-hari orang biasanya mensinonimkan pengertian budaya dengan tradisi (tradition). Dalam hal ini tradisi diartikan sebagai ideide umum, sikap dan kebiasaan dari masyarakat yang nampak dari perilaku sehari-hari yang menjadi kebiasaan dari kelompok dalam masyarakat tersebut. Koentjaraningrat memberikan definisi budaya sebagai sistem gagasan, tindakan dan hasil karya manusia dalam rangka kehidupan masyarakat yang dijadikan milik diri manusia dengan belajar ${ }^{18}$.

Selanjutnya, Koentjaraningrat mendefinisikan budaya sebagai "keseluruhan sistem gagasan tindakan dan hasil karya manusia dalam rangka kehidupan masyarakat yang dijadikan milik diri manusia dengan cara belajar". Lebih lanjut, Koentjaraningrat membagi kebudayaan dalam tiga wujud yaitu:sebagai suatu kompleksitas dari ide-ide, gagasan, nilai-nilai, norma-norma, peraturan dan lain-lain;sebagai suatu kompleksitas

${ }_{16}$ Mulyasa, E., Manajemen Berbasis Madrasah, Konsep, Strategi dan Implementasi, (Bandung: PT. Remaja Rosdakarya, 2003), 126.

${ }^{17}$ Depdikbud.Manajemen Peningkatan Mutu Pendidikan Berbasis Sekolah.(Jakarta: Depdikbud, 1997), 149.

${ }^{18}$ Koentjaraningrat, Pengantar Ilmu Antropologi, (Jakarta: Rineka Cipta, 1990), 180. 
aktivitas kelakuan berpola dari manusia dalam masyarakat dan;dan sebagai bendabenda hasil karya manusia. ${ }^{19}$

Madrasah merupakan tempat berlangsungnya kegiatan belajar mengajar. Belajar dan mengajar tidak hanya dimaknai sebagai kegiatan transfer ilmu pengetahuan dari guru ke siswa. Berbagai kegiatan seperti bagaimana membiasakan seluruh warga madrasah disiplin dan patuh terhadap peraturan yang berlaku di madrasah, saling menghormati, membiasakan hidup bersih dan sehat serta memiliki semangat berkompetisi secara fair dan sejenisnya merupakan kebiasaan yang harus ditumbuhkan di lingkungan madrasah sehari-hari. Zamroni mengatakan bahwa kebiasaan-kebiasaan, nilai-nilai, norma, ritual, mitos yang dibentuk dalam perjalanan panjang madrasah disebut budaya madrasah. Budaya madrasah dipegang bersama oleh Kepala Madrasah, guru, staf aministrasi, dan siswa sebagai dasar mereka dalam memahami dan memecahkan berbagai persoalan yang muncul di madrasah. Madrasah menjadi wadah utama dalam transmisi kultural antar generasi ${ }^{20}$.

Menurut Bennet istilah culture digunakan sebagai payung istilah (umbrella term) yang merujuk pada semua aktivitas dan praktek-praktek yang menghasilkan pemahaman (sense) atau makna (meaning). Menurutnya, budaya berarti :

"Kebiasaan dan ritual yang mengatur dan menetukan hubungan sosial kita berdasarkan kehidupan sehari-hari sebagaimana halnya dengan teks-teks tersebut-sastra, musik, televisi, dan film-dan melalui kebiasaan serta ritual tersebut dunia sosial dan natural ditampilkan kembali atau ditandai-dimaknaidengan cara tertentu yang sesuai dengan konvensi tertentu. ${ }^{21}$,

Kajian budaya (CS) sebagai suatu disiplin ilmu (akademik) yang mulai berkembang di wilayah Barat (1960-an), seperti Inggris, Amerika, Eropa (kontinental), dan Australia mendasarkan suatu pengetahuan yang disesuaikan dengan konteks keadaan dan kondisi etnografi serta kebudayaan mereka.Pada tahap kelanjutannya di era awal abad 21 kajian budaya dipakai di wilayah Timur untuk meneliti dan menelaah konteks sosial di tempat-tempat yang jarang disentuh para

\footnotetext{
${ }^{19}$ Koentjoroningrat,Kebudayaan Mentaliter dan Pemberdayaan. (Jakarta: PT. Bumi Aksara, 1974). ${ }^{20} \mathrm{http}$ ///blog.umy.ac.id/wiwinsundari/2011/11/09/budaya-madrasah-school-culture/ ${ }^{21}$ Tony Bennet, "Popular Culture : A Teaching Object, Screen Education" (1980) yang dikutip dalam buku Keith Tester, Media, Budaya dan Moralitas, terj. Muhammad Syukri, Kreasi Wacana dan Juxtapose, 2003, 82-90.
} 
praktisi kajian budaya Barat, antara lain Afrika, Asia, atau Amerika Latin.Secara institusional, kajian budaya menelurkan berbagai karya berupa buku-buku, jurnal, diktat, matakuliah bahkan jurusan di universitas-universitas.

Menurut Barker, inti kajian budaya bisa dipahami sebagai kajian tentang budaya sebagai praktik-praktik pemaknaan dari representasi ${ }^{22}$. Teori budaya marxis yang menggali kebudayaan sebagai wilayah ideologi yang lebih banyak dijelaskan pada aliran wacana (discourse) dan praktik budaya seperti layaknya media berupa teks-teks (sosial, ekonomi, politik).Di samping itu, Chris Barker mengakui bahwa kajian budaya tidak memiliki titik acuan yang tunggal.Selain itu, kajian budaya memang terlahir dari indung alam pemikiran strukturalis/pascastrukturalis yang multidisipliner dan teori kritis multidisipliner, terutama di Inggris dan Eropa kontinental. Artinya kajian budaya mengkomposisikan berbagai kajian teoritis disiplin ilmu lain yang dikembangkan secara lebih longgar sehingga mencakup potongan-potongan model dari teori yang sudah ada dari para pemikir strukturalis/pascastrukturalis. Sedangkan teori sosial kritis sebenarnya sudah mendahului tradisi disiplin "kajian budaya" melalui kritik ideologinya yang dikembangkan Madzhab Frankfurt.Sebuah kritik yang dimaknai dari pandangan Kantian, Hegelian, Marxian, dan Freudian. Sehubungan dengan karakter akademis, pandangan lain dari Ben Agger membedakan kajian budaya sebagai gerakan teoritis, dan kajian budaya sebagai mode analisis dan kritik budaya ateoritis yang tidak berasal dari poyek teori sosial kritis, yaitu kritik ideologi ${ }^{23}$.

Beberapa pendapat yang dikemukakan di atas dapat disimpulkan bahwa budaya adalah sesuatu yang abstrak, tetapi tetap memiliki dimensi yang mencolok, dapat didefinisikan dan dapat diukur berdasarkan karakteristik umum seperti yang dikemukakan oleh Robbins sebagai berikut: (1) inisiatif individual; (2) toleransi terhadap tindakan beresiko; (3) arah; (4) integrasi; (5) dukungan dari manajemen; (6) kontrol; (7) identitas; (8) sistem imbalan; (9) toleransi terhadap konflik; dan (10) polapola komunikasi. ${ }^{24}$

Menurut Kujala dan Ullrank, untuk memahami pengertian budaya mutu hendaknya dipahami terlebih dahulu akar dari budaya mutu yaitu budaya madrasah,

${ }^{22}$ Barker, Chris, Cultural Studies: Teori dan Praktik, Terj. (Bentang: Tim KUNCI Cultural Studies Centre, 2005), 10.

${ }^{23}$ Agger, Ben, Teori Sosial Kritis, (Kreasi Wacana, Yogjakarta, 2003)

${ }^{24}$ Robins, Teori Madrasah (Struktur, Desain \& Aplikasi). (Jakarta: Salemba Empat, 1994) 
karena budaya mutu merupakan subset dari budaya madrasah. ${ }^{25}$ Menurut Robbins, budaya madrasah merupakan sistem makna bersama terhadap nilai-nilai primer yang dianut bersama dan dihargai madrasah, yang berfungsi menciptakan pembedaan yang jelas antara satu madrasah dengan madrasah lainnya, menciptakan rasa identitas bagi para anggota madrasah, mempermudah timbulnya komitmen kolektif terhadap madrasah, meningkatkan kemantapan sistem sosial, serta menciptakan mekanisme pembuat makna dan kendali yang memandu membentuk sikap dan perilaku para anggota madrasah. ${ }^{26}$ Deal dan Kennedy sebagaimana dikutip Robbins menjelaskan budaya madrasah sebagai nilai-nilai dominan yang didukung madrasah. ${ }^{27}$

Dengan demikian, budaya madrasah dapat dikatakan bermutu bilamana memungkinkan bertumbuhkembangnya madrasah dalam mencapai suatu keberhasilan pendidikan.Budaya mutu madrasah adalah keseluruhan latar fisik, lingkungan, suasana, rasa, sifat, dan iklim madrasah secara produktif mampu memberikan pengalaman dan tumbuh kembangnya madrasah untuk mencapai keberhasilan pendidikan berdasarkan spirit dan nilai-nilai yang dianut oleh madrasah. Terdapat delapan elemen budaya mutu madrasah,yaitu: informasi kualitas untuk perbaikan, bukan untuk mengontrol; kewenangan harus sebatas tanggungjawab; hasil diikuti rewards atau punishmen; kolaborasi, sinergi, bukan persaingan sebagai dasar kerjasama; warga madrasah merasa aman terhadap pekerjaannya; atmosfir keadilan; imbal jasa sepadan dengan nilai pekerjaan; dan warga madrasah merasa memiliki madrasah.

Dale menjelaskan beragamnya definisi budaya madrasah yang dikemukakan para ahli menggambarkan kompleksitas budaya madrasah.Diperlukan upaya menghasilkan budaya madrasah yang kondusif bagi perbaikan berkelanjutan dimana setiap orang dapat berpartisipasi. Jaminan kualitas juga perlu diintegrasikan ke dalam semua proses dan fungsi madrasah. Semua itu memerlukan perubahan perilaku orang-orang, sikap mental dan praktek pekerjaan dalam berbagai cara. Seperti, merubah perilaku dan sikap mental orang adalah salah satu tugas manajemen yang

\footnotetext{
${ }^{25}$ Kujala, J.; P. Ullrank..Total Quality Management as a Cultural Phenomenon. Online. (Tersedia: www.asq.org. 2004), 48.

26 Robbins, Stephen P., Organizational Behavior. (New Jersey: Pearson Education International. 2001), 525.

${ }^{27}$ Ibid, 479.
} 
paling sulit, memerlukan kekuatan besar dan keterampilan persuasif dan memotivasi.Kesungguhan juga diperlukan dalam memfasilitasi dan mengelola perubahan menuju ke arah budaya kualitas. ${ }^{28}$

Budaya madrasah (school culture) merupakan kata kunci (key word) yang perlu mendapat perhatian secara sungguh-sungguh dari para pengelola pendidikan.Budaya madrasah perlu dibangun berdasarkan kekuatan karakteristik budaya lokal masyarakat tempat madrasah itu berada.Budaya madrasah adalah detak jantung madrasah itu sendiri, perumusannya harus dilakukan dengan sebuah komitmen yang jelas dan terukur oleh komunitas madrasah yakni guru, siswa, manajemen madrasah, dan masyarakat.

Proses membangun atmosfir budaya madrasah yang kondusif, maka ada baiknya kita mengenal terlebih dahulu apakah yang dimaksud dengan budaya madrasah, bagaimana penciptaannya, bagaimana peran kepala madrasah selaku leader dalam mendisain budaya madrasahnya, bagaimana hasil dari budaya madrasah kontribusinya terhadap keberhasilan madrasah baik dalam meningkatkan kualitas sumber daya manusia maupun prestasi madrasahya.

Manusia merupakan makhluk unik karena manusia terdiri kumpulan kehidupan yang mempunyai budaya. Budaya memiliki elemen yang membedakan manusia dengan hidupan lain. Istilah "kebudayaan" banyak digunakan dalam bidang antropologi budaya. Dalam disiplin antropologi budaya ${ }^{29}$, tiada perbedaan makna di antara kata "budaya" dengan "kebudayaan"30.

Konsep tentang kebudayaan banyak dan rumit.Penguraian mengenai konsep ini mengundang berbagai kekeliruan kesan daripada perbedaan disiplin dan perspektif kebudayaan itu dilihat oleh para pengkaji.Bahkan lebih merumitkan apabila melibatkan emosi.Konsep ini perlu difahami bersasama dari aspek praktikal maupun teoritikal.

${ }^{28}$ Yoder, Dale, Personel Principles and Policies, (Maruzen Company Ltd : Prentice Hall Inc, Second Edition. 2003), 30.

${ }^{29}$ Koentjaraningrat, Pengantar Ilmu Antropologi . (Kuala Lumpur : Pustaka Antara, 1970)

${ }^{30}$ Hashim Awang A.R., Budaya dan Kebudayaan :Teori, Isu dan Persoalan. (Kuala Lumpur : Citra Budaya. 1998) 
Setiap definisi sering kali dipengaruhi oleh kerangka teori dan pengandaian mengenai asas pembentukan masyarakat dan kebudayaan itu sendiri. ${ }^{31}$ Sebagai contoh teori evolutionism $^{32}$ dipelopori oleh Edward Burnett Tylor, teori historical particularis ${ }^{33}$ atau historical diffusionism oleh Franz Boas, teori culture and personality ${ }^{34}$ oleh Ralph Linton, teori fungtionalis ${ }^{35}$ oleh Bronislaw Malinowski, teori structural-functionalism ${ }^{36}$ oleh Alfred Reginald Radcliffe-Brown, teori structuralism ${ }^{37}$ oleh Claude Lévi-Strauss dan sebagainya. $^{38}$

Pada umumnya, kata "kebudayaan" 39 yang berarti peradaban atau kemajuan pikiran. ${ }^{40}$ Dari sudut etimologi, kata "budaya" berasal dari akar kata yang tersusun dari dua kata yang terpisah yaitu "budi" dan "daya". Kalimat "budi" berarti cahaya atau sinar yang terletak di dalam batin manusia. Kata "daya" berkaitan dengan upaya yaitu usaha, keaktifan manusia melaksanakan dengan anggotanya yang digerakkan oleh budinya. Pandangan ini didukung oleh Haji Abdul Karim Amrullah ${ }^{41}$ dan Sutan TakdirAlisjahbana ${ }^{42}$ Perkataan budaya mengalami proses hiplologi 43 (budi+daya: budaya). Bertentangan dengan Koentjaraningrat kerana beliau berpendapat istilah "budaya"berasal dari bahasa Sansekerta "buddhayah" yaitu kata jamak dari perkataan "buddhi" yang berarti budi atau akal. Dengan demikian,

31 Zainal Kling, "Konsep Kebudayaan Kebangsaan Malaysia” dalam Pertemuan Dunia Melayu '82 . (KualaLumpur : Dewan Bahasa dan Pustaka. 1987)

${ }^{32}$ Edward B. Tylor, Primitive Culture . (New York : Harper Torchbooks. 1958)

${ }^{33}$ Franz Boas, Race, Language and Culture. (New York : Mac Millan. 1940)

${ }^{34}$ Ralph Linton, The Cultural Background of Personality. (London : Routledge \& Kegan Paul. 1968)

${ }^{35}$ Bronislaw Malinowski, A Scientific Theory of Culture. (New York : Oxford University Press. 1960)

${ }^{36}$ A.R. Radcliffe-Brown, Structure and Function in Primitive Society. (London : Cohen \& West, 1952)

${ }^{37}$ Claude Lévi-Strauss, Structural Anthropology.New York : Basic Books Inc, 1963)

${ }^{38}$ Aliran-aliran lain adalah neo-evolutionism, ethno-sciences, cultural ecology dan sebagainya.

${ }^{39}$ Dalam bahasa Inggeris dipanggil culture, Latin cultus ,Jerman kultur, Itali cultura , Parsi farhang, Mandarin wenhua dan bahasa Arab al-thaq a fah.

${ }^{40}$ Hajah Noresah Baharom et al. (eds.), Kamus Dewan . Edisi Keempat, (Kuala Lumpur : Dewan Bahasa danPustaka, 2005)

${ }^{41}$ Haji Abdul Malik Karim Amrullah, Pandangan Hidup Muslim . Cetakan Kedua, Jakarta : Bulan Bintang, 1966)

${ }^{42}$ Sutan Takdir Alisjahbana, Perkembangan Sejarah Kebudayaan Indonesia Piliban dari Jurusan Nilai- nilai . Cetakan Ketiga, (Jakarta : PT. Dian Rakyat, 1982)

${ }^{43}$ Bunyi yang sama berdekatan antara satu kata. Salah satu dihilangkan. 
kebudayaan dapat diertikan sebagai hal-hal yang bersangkutan dengan akal ${ }^{44}$ Begitu juga Bakkar dalam buku Filsafat Kebudayaan: Sebuah Pengantar yang mendakwa perkataan budaya berasal dari perkataan Sanskrit " Abhudaya” yang bererti hasil baik, kemajuan dan kemakmuran yang serba lengkap ${ }^{45}$.

Secara umum pengertian "mutu" adalah kualitas.Kualitas sebuah pendidikan mencakup kinerja Kepala Madrasah, pelayanan guru terhadap siswa, pelayanan lembaga terhadap masyarakat, prestasi siswa secara akademik dan non akademik, serta terkahir kualitas lulusan dalam setiap tahun. Untuk lebih medalami pengertian mutu suatu pendidikan di bawah ini dipaparkan pengertian tang mutu dari beberapa ahli. Pandangan Suharsaputra mengatakan konsep mutu lebih berkembang dalam dunia bisnis yang kemudian berpengaruh juga pada dunia pendidikan, sehingga masalah mutu belakangan menjadi consern/perhatian dakam upaya membangun pendidikan.Untuk itu diperlukan pengelolaan mutu yang tepat termasuk dalam dunia pendidikan mengingat secara legal pendidikan pun harus melakukan penjaminan mutu dalam rangka terus-menerus meningkatkan mutu pendidikan ${ }^{46}$.

Konsep mutu memiliki pengertian yang berbeda-beda.Hal dapat menambah wawasan untuk memahami definisi mutu yang lebih luas. Di bawah ini terdapat beberapa pendapat yang merumuskan definisi mutu, antara lain:mutu adalah kecocokan penggunaan produk (fitness for use) untuk memenuhi kebutuhan dan kepuasan pelanggan; mutu adalah conformance to requirement, yaitu sesuai dengan yang diisyaratkan atau yang distandarkan; mutu adalah kesesuaian dengan kebutuhan pasar atau konsumen; dan mutu adalah kepuasan pelanggan sepenuhnya (full customer satisfaction). ${ }^{47}$

Pendidikan yang berfokus pada mutu menurut konsep Jerome adalah bahawa dasar misi mutu sebuah madrasah mengembangkan program dan layanan yang

\footnotetext{
${ }^{44}$ Koentjaraningrat, Pengantar Antropologi, (Jakarta: Pustaka Antara, 1970)

${ }^{45}$ Hashim Awang A.R. Budaya dan Kebudayaan. Teori, Isu, dan Persoalan, (Kuala Lumpur: Citra Budaya, 1998)

46Suharsaputra, Administrasi Pendidikan, (Bandung: PT. Refika Aditama, 2010), 255-256.

${ }^{47}$ Nasution M.N., Manajemen Mutu Terpadu .Total Quality Manajement, (Jakarta: Galia Indonesia, 2001), 15-16.
} 
memenuhi kebutuhan pengguna seperti siswa dan masyarakat. ${ }^{48}$ Masyarakat dimaksud adalah secara luas sebagai pengguna lulusan, yaitu dunia usaha, lembaga pendidikan lanjut, pemerintah dan masyarakat luas, termasuk menciptakan usaha sendiri oleh lulusan.

Menurut Crosby, mutu adalah sesuai yang diisyaratkan atau distandarkan (Conformance to Requirement), yaitu sesuai dengan standar mutu yang telah ditentukan, baik inputnya, prosesnya maupun outputnya. ${ }^{49}$ Oleh karena itu, mutu pendidikan yang diselenggarakan madrasah dituntut untuk memiliki mutu baku standar mutu pendidikan. Dalam konsep Deming, mutu adalah kesesuaian dengan kebutuhan pasar. ${ }^{50}$ Dalam konsep Deming, pendidikan yang bermutu adalah pendidikan yang dapat menghasilkan keluaran, baik pelayanan dan lulusan yang sesuai kebutuhan atau harapan pelanggan (pasar)nya sedangkan Fiegenbaum mengartikan mutu adalah kepuasan pelanggan sepenuhnya (full customer satisfaction). ${ }^{51}$ Dalam pengertian ini, maka yang dikatakan madrasah bermutu adalah madrasah yang dapat memuaskan pelanggannya, baik pelanggan internal maupun eksternal.

Mutu menurut Carvin, sebagaimana yang dikutip Nasution, adalah suatu kondisi dinamis yang berhubungan dengan produk, manusia/tenaga kerja, proses dan tugas, serta lingkungan yang memenuhi atau melebihi harapan pelanggan atau konsumen. Selera atau harapan pelanggan pada suatu produk selalu berubah, sehingga kualitas produk juga harus berubah atau disesuaikan. Dengan perubahan mutu produk tersebut, diperlukan perubahan atau peningkatan keterampilan tenaga kerja, perubahan proses produksi dan tugas, serta perubahan lingkungan madrasah agar produk memenuhi atau melebihi harapan pelanggan. ${ }^{52}$

Berdasarkan beberapa definisi di atas dapat ditarik kesimpulan bahwa pengertian mutu mengandung tiga unsur, yaitu: (1) kesesuaian dengan standar; (2) kesesuaian dengan harapan stakeholders; dan (3) pemenuhan janji yang diberikan. Definisi mutu memiliki konotasi yang bermacam-macam bergantung orang yang

\footnotetext{
${ }^{48}$ Jerome S., Quality in Education An Implementation Hanndbook, Alih Bahasa: Yosal Iriantara, (Yogyakarta: Pustaka Belajar, Cetakan 1, 2005), 8.

${ }^{49}$ Philip B. Crosby, Quality is Free (New York: New American Library, 1979), 58.

${ }^{50}$ Deming W.Edward, Out of Crisis (Cambridge: Massachussets Institute of Technology, 1986), 176.

51 Armand V. Fiegenbaum, Total Quality Control, 3rd Edition (1991), 7.

${ }^{52}$ Nasution M.N., Manajemen Mutu Terpadu, (Jakarta: Galia Indonesia, 2001), 16.
} 
memakainya. Mutu berasal dari bahasa latin yakni "Qualis" yang berarti what kind of (tergantung kata apa yang mengikutinya). Mutu menurut Deming ialah kesesuaian dengan kebutuhan.Mutu menurut Juran ialah kecocokan dengan kebutuhan. ${ }^{53}$

Ditinjau dari sudut hukum, dipinisi pendidikan berdasarkan undang-undang RI Nomor 20 tahun 2003 tentang Sistem Pendidikan Nasional (Sisdiknas), pasal 1 (1 dan 4) yaitu pendidikan adalah usaha sadar dan terencana untuk mewujudkan suasana belajar dan proses pembelajaran agar peserta didik secara aktif mengembangkan potensi dirinya untuk memiliki kekuatan spiritual keagamaan, pengendalian diri, keperibadian, kecerdasan, akhlak mulia, serta keterampilan yang diperlukan dirinya, masyarakat, bangsa dan negara. Peserta didik adalah anggota masyarakat yang berusaha mengambangkan potensi diri melalui proses pembelajaran yang tersedia pada jalur, jenjang, dan jenis pendidikan. Menurut Sunario seperti dikutip Usman potensi otak manusia yang digunakan untuk barpikir baru 4\%.Jadi, masih 96\% dari otak manusia yang belum digunakan untuk berpikir. ${ }^{54}$ Mutu di bidang pendidikan meliputi mutu input, proces, output, dan outcome. Input pendidikan dinyatakan bermutu jika siap berperoses. Proses pendidikan bermutu apabila mampu menciptakan suasana yang PAKEM (Pembelajaran yang Aktif, Kreatif, dan Menyenangkan).

Menurut Hari Sudradjad, pendidikan yang bermutu adalah pendidikan yang mampu menghasilkan lulusan yang memiliki kemampuan atau kompetensi, baik kompetensi akademik maupun kompetensi kejuruan, yang dilandasi oleh kompetensi personal dan sosial, serta nilai-nilai akhlak mulia, yang keseluruhannya merupakan kecakapan hidup (life skill), lebih lanjut Sudradjat megemukakan pendidikan bermutu adalah pendidikan yang mampu menghasilkan manusia seutuhnya (manusia paripurna) atau manusia dengan pribadi yang integral (integrated personality) yaitu mereka yang mampu mengintegralkan iman, ilmu, dan amal. ${ }^{55}$ Namun untuk dapat meningkatkan mutu pendidikan, maka madrasah harus melaksanakan Manajemen Berbasis Madrasah (MBS) yang berorientasi pada peningkatan mutu.Jadi, konsep budaya dan mutu yang berkaitan dengan madrasah tersebut dan beberapa konsep

${ }^{53}$ Usman, Husaini, Manajemen Teori, Praktek Dan Riset Pendidikan, (Jakarta : Bumi Aksara, 2006), 407.

${ }^{54}$ Ibid., 7.

${ }^{55}$ Suderadjat, Hari, Manajemen Peningkatan Mutu Berbasis Madrasab; Peningkatan Mutu Pendidikan Melalui Implementasi KBK, (Bandung: Cipta Lekas Garafika, 2005), 17. 
yang dikemukakan oleh para ahli di atas dapat ditarik kesimpulan tentang konsep budaya mutu yaitu suatu kebiasaan dalam menilai perkembangan individual atau kelompok secara rohani maupun jasmani sesuai visi dan misi madrasah.

\section{Dasar Ajaran Islam tentang Mutu}

Menurut Muhaimin ${ }^{56}$ (dalam Mulyadi), dasar ajaran Islam tentang mutu sebagai berikut:Mutu merupakan realisasi dari ajaran ihsan, yakni berbuat baik pada semua pihak disebabkan karena Allah telah berbuat baik kepada manusia dengan aneka nikmat-Nya, dan dilarang berbuat kerusakan dalam bentuk apapun ${ }^{57}$. Sebagaimana yang tersebut dalam Al-qur'an surat al Qashas yang artinya: "Dan carilah pada apa yang telah dianugerabkan Allah kepadamu (kebahagiaan) negeri akbirat, dan janganlah kamu melupakankebahagiaanmu dari (kenikmatan) duniawi dan berbuat baiklah (kepada orang lain) sebagaimana Allah telah berbuat baik. kepadamu, dan janganlah kamu berbuat kerusakan di (muka) bumi. Sesunggubnya Allab tidak menyukai orang-orang yang berbuat kerusakan". 58

Seseorang tidak boleh bekerja dengan sembrono (seenaknya) dan acuh tak acuh sebab akan berarti merendahkan makna demi ridha Allah atau merendahkan Tuhan. Dalam Al-qur'an surat Al Kahfi disebutkan bahwa "Katakanlah aku sesunggubnya aku ini manusia biasa seperti kamu, yang diwabyukan kepadaku: "Babwa sesunggubnya Tuban kamu itu adalah Tuhan yang Esa”. Barang siapa yang mengharap perjumpaan dengaan Tubannya, maka hendaklah ia mengerjakan amal yang saleh dan janganlah ia mempersekutukan seorangpun dalam beribadat kepda Tubannya."

Maksud dari kata "Mengerjakan amal saleb" dalam ayat di atas adalah bekerja dengan baik (bermutu), sedangkan kata "Janganlah ia mempersekutukan seorang pun dalam beribadat kepada Tuhannya" berarti tidak mengalihkan tujuan pekerjaan selain kepada Tuhan (Al-Haqq) yang menjadi sumber nilai intrinsik pekerjaan manusia.Setiap orang dinilai dari hasil kerjanya ${ }^{60}$, seperti yang telah dijelaskan dalam Al-qur'an surat An Najm disebutkan bahwa "Dan bahwasanya seorang manusia tiada memperoleh selain apa yang telah diusahakannya".

\footnotetext{
${ }^{56}$ Mulyadi, Kepemimpinan Kepala, 79.

${ }^{57}$ Ibid.

58Sumber: Al- qur'an, Surat Al Qoshas, ayat 77.

59 Sumber: Al- qur'an, Surat Al Kabfi, ayat 110.

${ }^{60}$ Mulyadi, Kepemimpinan Kepala Madrasah dalam Mengembangkan Budaya Mutu, (Malang, 2010), 80 .
} 
Berdasarkan ayat di atas, maka setiap orang dalam bekerja dituntut untuk: (1) tidak memandang enteng bentuk-bentuk kerja yang dilakukan; (2) memberi makna kepada pekerjaannya itu; (3) insaf bahwa kerja adalah mode of existence (bentuk keberadaan manusia); dan (4) dari segi dampaknya (baik/buruknya), kerja itu tidaklah unntuk Tuhan, tetapi untuk dirinya sendiri. Sesuai dengan Al-qur'an surat Fushshilat" ${ }^{61}$ ang artinya: "Barang siapa cyang mengerjakan amal yang saleh maka (pahalanya) untuk dirinya sendiri dan barang siapa mengerjakan perbuatan jahat, maka (dosanya) untuk dirinya sendiri: dan sekali-kali tidaklah Rabb-mu menganiaya hamba-hamba-Nya. ${ }^{62}$

Seseorang harus bekerja secara optimal dan komitmen terhadap proses dan hasil kerja yang bermutu atau sebaik mungkin ${ }^{63}$, selaras dengan ajaran ihsan. Hal ini dijelaskan dalam Al-qur'an surat An-Nahl yaitu "Sesunggubnya Allab menyurub (kamu) berlaku adil dan berbuat kebajikan, memberi kepada kaum kerabat, dan Allah melarang dari perbuatan keji, kemungkaran dan permusuban, dia memberi pengajaran agar kamu dapat mengambil pelajaran". ${ }^{64}$

\section{Tujuan dan Manfaat Pengembangan Budaya Mutu}

Hasil pengembangan budaya mutu adalah meningkatkan perilaku yang konsisten dan untuk menyampaikan kepada personil madrasah tentang bagaimana perilaku yang seharusnya dilakukan untuk membangun kepribadian mereka dalam lingkungan madrasah yang sesuai dengan iklim lingkungan yang tercipta di madrasah baik itu lingkungan fisik maupun iklim kultur yang ada.

Pemahaman bahwa budaya dan iklim madrasah mempunyai sifat yang sama, tidak berarti bahwa tidak akan terdapat sub-budaya di dalam budaya madrasah. Oleh karena itu budaya yang terbentuk dalam lingkungan madrasah yang merupakan karakteristik madrasah adalah budaya dominan atau budaya yang kuat, dianut, diatur dengan baik dan dirasakan bersama secara luas. Makin banyak personil madrasah yang menerima nilai-nilai inti, menyetujui gagasan berdasarkan kepentingannya, dan merasa sangat terikat pada nilai yang ada maka makin kuat budaya tersebut. Oleh karena, para personil madrasah memiliki pengalaman yang diterima bersama, sehingga dapat menciptakan pengertian yang sama. Hal ini bukan berarti bahwa

${ }^{61} \mathrm{Al}$-qur'an, Surat An Najm, ayat 39

62 Al-qur'an, Surat Al Fusbilat, ayat 46

${ }^{63}$ Mulyadi, Kepemimpinan Kepala, 81.

${ }^{64} \mathrm{Al}$-qur'an, Surat An Nabl, ayat 90 
anggota yang stabil memiliki budaya yang kuat karena nilai inti dari budaya madrasah harus dipertahankan dan dijunjung tinggi, namun juga harus dinamis.

Manfaat yang diperoleh dengan pengembangan budaya dan iklim madrasah yang kuat, intim, kondusif dan bertanggung jawab adalah:menjamin kualitas kerja yang lebih baik; membuka seluruh jaringan komunikasi dari segala jenis dan level baik komunikasi vertikal maupun horisontal; lebih terbuka dan transparan; menciptakan kebersamaan dan rasa saling memiliki yang tinggi; meningkatkan solidaritas dan rasa kekeluargaan; jika menemukan kesalahan akan segera dapat diperbaiki; dan dapat beradaptasi dengan baik terhadap perkembangan IPTEK.

Manfaat ini bukan hanya dirasakan dalam lingkungan madrasah, tetapi dimana saja karena dibentuk oleh norma pribadi dan bukan oleh aturan yang kaku dengan berbagai hukuman jika terjadi pelanggaran yang dilakukan, selain beberapa manfaat diatas, manfaat lain bagi individu (pribadi) dan kelompok adalah:meningkatkan kepuasan kerja; pergaulan lebih akrab; disiplin meningkat; pengawasan fungsional bisa lebih ringan; muncul keinginan untuk selalu ingin berbuat proaktif; belajar dan berprestasi; dan selalu ingin memberikan yang terbaik bagi madrasah, keluarga, orang lain dan diri sendiri.

\section{Jenis-Jenis Budaya Mutu}

Menurut Mulyadi, jenis-jenis budaya mutu, yaitu: (1) artefak, yaitu hal-hal yang terlihat, terdengar dan terasakan ketika oleh seseorang dari luar madrasah ketika memasuki madrasah tersebut yang sebelumnya tidak dikenalnya. Secara fisik artefak dapat dilihat dari produk, jasa dan tingkah laku anggota madrasah yang bersangkutan. Di dalam madrasah itu sendiri, artefak antara lain tampak dalam struktur dan prosesproses organisasi ${ }^{65}$; (2) morma dalam madrasah tampak dalam aturan-aturan tertulis maupun kesepakatan tidak tertulis. Di dalamnya mengandung arahan positif dan saksi terhadap pelanggaran dalam madrasah ${ }^{66}$; (3) nilai-nilai yang ada dalam organisai yang menjadi daya tarik, sehingga orang di luar madrasah tersebut tertarik untuk masuk ke dalamnya. Dari sisi madrasah, nilai-nilai tersebut akan tampak pada tujuan dan strategi madrasah. ${ }^{67}$

${ }^{65}$ Mulyadi, Kepemimpinan Kepala, 93.

${ }^{66}$ Ibid.

${ }^{67}$ Ibid. 
Pada umumya, persoalannya madrasah dan madrasah khususnya disinyalir banyak yang belum memiliki budaya yang kuat terutama yang tipenya adaptif.Jika kenyataannya demikian, maka perlu dilihat secara lebih rinci budaya yang berkembang di madrasah.Secara teoritis, untuk melihat budaya madrasah dapat digunakan dua indikator inti, yaitu fleksibilitas dan fokus dari aktivitas madrasah.Fleksibilitas dapat dilihat dari dua titik ekstrim, yaitu fleksibel dan statis.Fokus dapat dilihat dari dua sisi, yaitu internal dan eksternal.Apabila menggunakan dua indikator yang masing-masing memiliki dua kutub, maka dapat dibuat dengan empat tipe budaya madrasah.Pertama, apabila madrasah dapat dengan mudah dan cepat menyesuaikan diri dan mengarah pada internal, maka budaya yang berkembang adalah budaya adaptif.Budaya adaptif adalah budaya yang tumbuh dan berkembang dipengaruhi oleh faktor internal dimana faktor ini menjadi pendukung sekaligus penghambat terbentuknya budaya mutu madrasah.Kedua, apabila madrasah formalitas hubungan internal madrasah maupun pihak eksternal madrasah, maka sebuah madrasah yang birokratis memiliki struktur dan proses kerja yang jelas dan tidak dapat diubah segera. Hal ini dirancang untuk mengatur pola hubungan yang baku dan formal. Hubungan keduanya meliputi: (1) mementingkan efisiensi; (2) pembakuan-pembakuan dan formalitas yang diarahkan untuk mencapai efisiensi; (3) menekankan rasionalitas; (4) indikator ini merupakan dasar dari berbagai hal, termasuk efisiensi, keteraturan, dan kepatuhan; (5) teratur dan berjenjang; dan (6) menuntut adanya kepatuhan dari pihak-pihak di bawah pimpinan. Ketiga, apabila madrasahnya cenderung stabil (tidak fleksibel) dan arahnya ke faktor eksternal maka budaya yang berkembang adalah budaya prestasi. Dan keempat, apabila madrasah cenderung stabil dan mengarah ke faktor eksternal, maka budaya yang diperoleh adalah budaya birokrasi.

Secara lebih rinci, masing-masing budaya memiliki nilai-nilai yang dapat dijadikan ciri-ciri untuk mendeteksi keadaan di lapangan. Terdapat 2 fokus dalam jenis-jenis budaya, yaitu: (1) fokus eksternal; dan (2) fokus internal.Fokus Internal, yaitu budaya adaptif, memiliki ciri-ciri: kreatif, berani melakukan eksperimentasi. berani mengambil resiko, mandiri, dan responsive, dan budaya Prestasi, memiliki ciriciri: berorientasi pada persaingan atau kompetesi, mengumpulkan kesempurnaan, agresif, aktif dan rajin, dan mendorong munculnya inisiatif anggota, sedangkan fokus 
eksternal, yaitu budaya Kekeluargaan, memiliki ciri: mengedepankan kerjasama, penuh pertimbangan, persetujuan bersama, kesetaraan, dan keadilan, dan budaya Birokrasiadalah mesin pelaksana kebijakan. Efektivitas dan efisiensi kebijakan pemerintahan mendapat wujud nyatanya pada efektivitas dan efisiensi birokrasi.

Secara umum, budaya birokrasi memiliki keuntungan dan kelemahan.yaitu teori birokrasi ini mempunyai kekuatannya yang tersendiri, walaupun teori ini sering dikaitkan dengan negatif, namun teori birokrasi ini juga banyak memberikan sumbangan kepada teori dalam pengurusan sumber manusia. Secara hirarki dan definisi tanggung jawab merupakan ciri penting birokrasi dalam membantu pengurusan tempat kerja yang tersusun. Lakaran prinsipal terhadap semua tugas haruslah jelas dan disusun dalam bentuk hirarki. Adanya aturan, norma, dan prosedur untuk mengatur madrasah, sedangkan kelemahan budaya birokrasi, yaitu: 1) penetapan standar efisiensi yang dapat dilaksanakan secara fungsional; 2) terlalu menekankan aspek-aspek rasionalitas, impersonalitas dan hirarki; 3) kecenderungan birokrat untuk menyelewengkan tujuan-tujuan madrasah; dan 4) berlakunya pita merah dalam kehidupan madrasah.

\section{Bagian-Bagian Budaya Mutu}

Di era sekarang ini perkembangan Ilmu Pengetahuan dan Teknologi (IPTEK) semakin canggih dan terus mengglobal, sehingga berdampak pada hampir semua kehidupan umat manusia di muka bumi ini. Semakin berkembangnya IPTEK tersebut manusia dituntut untuk semakin maju pula. Peningkatan mutu pendidikan merupakan salah satu prioritas pembangunan di bidang pendidikan Nasional sekarang ini dan akan datang. Prioritas ini didasarkan pada kebijaksanaan yang lebih menekankan kepada perluasan dan kesempatan belajar, sehingga mutunya sedikit terabaikan.Selain itu, tuntutan terhadap mutu pendidikan semakin kuat sejalan dengan perkembangan dan pertumbuhan di setiap sektor kehidupan.

Berbagai upaya untuk meningkatkan mutu pendidikan sekarang sebenarnya telah, sedang dan akan terus dilaksanakan secara bertahap dan berkelanjutan. Mulai dari peningkatan kualitas pendidikan pra madrasah, dasar, menengah sampai dengan perguruan tinggi.Salah satu upaya yang dewasa ini sedang disosialisasikan dan dianggap tepat adalah melalui Total Quality Management (TQM) atau Manajemen Mutu Terpadu (MMT).Esensi dari TQM adalah suatu filosofi dan menunjuk pada 
perubahan budaya dalam suatu madrasah (pendidikan), serta dapat menyentuh hati dan pikiran orang menuju mutu yang diidamkan.

Nilai dan kepercayaan yang membangun budaya TQM meyakinkan bahwa anggota madrasah kerjasama untuk menyelesaikan kerja mereka dengan tujuan utama: Kualitas untuk pelanggan. Apabila TQM berguna untuk membangun elemen integral dari budaya madrasah, Seperangkat nilai dan kepercayaan merupakan bagian terpenting dari budaya tersebut. Nilai dan kepercayaan mengingatkan pada kita yang benar dan yang salah (if....then...).

Bentuk budaya sangat komplek, maka dalam membentuk budaya madrasah diperlukan kepercayaaan dan nilai yang saling mendukung serta melengkapi satu sama lain,agar dapat dimengerti dengan baik, salah satunya budaya TQM dibagi menjadi delapan elemen, yaitu: (a) etika; (b) integritas (kejujuran); (c) kepercayaan; (d) pelatihan (training); (e) kerja tim (team work); (f) kepemimpinan (leadership); ( $\mathrm{g}$ ) komunikasi; dan (h) penghargaan (recognition).

\section{Karakteristik Budaya Mutu dan Kriteria Mutu}

Berbicata tentang karakteristik mutu pendidikan, Usman Husaini dalam mengemukakan sebanyak 13 (tiga belas) karakteristik yang dimiliki oleh mutu pendidikan ${ }^{68}$ yaitu : kinerja (performa) yakni berkaitan dengan aspek fungsional madrasah meliputi: kinerja guru dalam mengajar baik dalam memberikan penjelasan meyakinkan, sehat dan rajin mengajar, dan menyiapkan bahan pelajaran lengkap, pelayanan administratif dan edukatif madrasah baik dengan kinerja yang baik setelah menjadi madrasah favorit; waktu wajar (timelines) yakni sesuai dengan waktu yang wajar meliputi memulai dan mengakhiri pelajaran tepat waktu, waktu ulangan tepat; handal (reliability) yakni usia pelayanan bertahan lama. Meliputi pelayanan prima yang diberikan madrasah bertahan lama dari tahun ke tahun, mutu madrasah tetap bertahan dan cenderung meningkat dari tahun ke tahun; daya tahan (durability) yakni tahan banting, misalnya meskipun krisis moneter, madrasah masih tetap bertahan; indah (aesteties) misalnya eksterior dan interior madrasah ditata menarik, guru membuat media-media pendidikan yang menarik; hubungan manusiawi (personal interface) yakni menunjung tinggi nilai-nilai moral dan profesionalisme. Misalnya

${ }^{68}$ Usman, Husaini, Manajemen Teori, Praktek Dan Riset Pendidikan, (Jakarta : Bumi Aksara, 2006), 411. 
warga madrasah saling menghormati, demokrasi, dan menghargai profesionalisme; mudah penggunaanya (easy of use) yakni Sarana dan Prasarana dipakai. Misalnya aturan-aturan madrasah mudah diterapkan, buku-buku perpustakaan mudah dipinjam dikembalikan tepat waktu; bentuk khusus (feature) yakni keuggulan tertentu misalnya madrasah unggul dalam hal penguasaan teknologi informasi (komputerisasi); standar tertentu (comformence to specification) yakniu memenuhi standar tertentu. Misalnya madrasah tetlah memenuhi standar pelayanan minimal; konsistensi (concistency) yakni keajegan, konstan dan stabil, misalnya mutu madrasah tidak menurun dari dulu hingga sekarang, warga madrasah konsisten dengan perkataanya; seragam (uniformity) yakni tanpa variasi, tidak tercampur. Misalnya madrasah melaksanakan aturan, tidak pandang bulu, seragam dal berpakaian; mampu melayani (serviceability) yakni mampu memberikan pelayanan prima. Misalnya madrasah menyediakan kotak saran dan saran-saran yang masuk mampu dipenuhi dengan baik, sehingga pelanggan merasa puas; dan ketepatan (acuracy) yakni ketepatan dalam pelayanan misalnya madrasah mampu memberikan pelayanan sesuai dengan yang diinginkan pelanggan madrasah.

Kriteria budaya mutu, menurut Baldridge yang dikutip oleh Mulyadi bahwa ukuran mutu berfokus pada 7 (tujuh) area topik yang secara integral dan dinamis saling berhubungan, yaitu "leadership, information and analysis, strategic quality planning, buman resource management, quality assurance product of product and service, quality result and customer satisfaction". ${ }^{69}$ Dari 7 (tujuh) area topik ukuran kualitas di atas, jika diukur dengan kriteria Baldridge Award (dalam Mulyadi) ${ }^{70}$ maka perbaikan sistem manajemen kualitas adalah sebagai berikut: area pemimpin; area analisis dan informasi; area perencanaan mutu strategis; area pengembangan sumber daya manusia; area manajemen kualitas proses; area hasil-hasil kualitas; dan area kepuasan pelanggan

\section{Metode Penelitian}

Pendekatan penelitian adalah desain yang mengatur penelitian agar peneliti memperoleh data yang tepat sesuai dengan karakteristik, sifat, dan tujuan penelitian.Pendekatan kualitatif, dimana data dikumpulkan dengan latar alami sebagai sumber data langsung.dan diharapkan mampu mendeskripsikan dan menemukan

${ }^{69}$ Daniel V. Hunt, Managing for Quality, (Illinois: Businness one Irwin Homewood, 1993)

${ }^{70}$ Mulyadi, Kepemimpinan Kepala ,83. 
secara menyeluruh mengenai strategi Kepala Madrasah dalam mengembangkan budaya mutu.

Data adalah catatan keterangan sesuai bukti dan kebenaran; bahan-bahan yang dipakai sebagai dukungan penelitian ${ }^{71}$ atau bahan nyata yang dapat dijadikan kajian analisis atau kesimpulan.Data atau informasi yang dicari mengenai konsep budaya mutu, upaya-upaya dalam mengembangkan budaya mutu, dan dampak aplikasinya. Data diperoleh dari nara sumber, maupun dokumen-dokumen yang berkaitan dengan fokus penelitian melalui wawancara mendalam, observasi partisipan, dan dokumentasi. Sumber data dalam penelitian ini dapat dibedakan menjadi dua yaitu manusia/orang dan bukan manusia.Sumber data manusia berfungsi sebagai subjek atau informan kunci (key informan), sedangkan sumber data bukan manusia, tetapi berupa dokumen yang relevan dengan fokus penelitian, seperti gambar, foto, catatan rapat atau tulisan-tulisan yang ada kaitannya dengan fokus penelitian.Jenis data dalam penelitian kualitatif berupa kata-kata, dan tindakan, selebihnya berupa data tambahan seprti dokumen dan lain-lain ${ }^{72}$.

Instrumen penelitian merupakan alat untuk memahami makna dan penafsiran terhadap fenomena dan simbol-simbol interaksi di tiga madrasah tersebut, dibutuhkan keterlibatan dan penghayatan langsung peneliti terhadap objek dilapangan.Instrumen penelitian ini adalah peneliti sendiri yang kedudukannya sebagai perencana, pelaksana pengumpul data, analisis data, penafsir data, dan sebagai pelapor hasil penelitian. Peneliti menggunakan panduan observasi dan wawancara untuk memperlancar proses penelitian. Upaya-upaya peneliti, yaitu: (a) memahami upaya-upaya menyusun instrumen penyusunan data; (b) mengetahui hal-hal yang harus dipertimbangkan, dan (c) peneliti mengetahui komponen-komponen yang dipakai untuk melengkapi instrumen.

\section{Prosedur Pengumpulan Data}

Pengumpulan data untuk suatu tulisan ilmiah dapat dilakukan melalui observasi. Observasi adalah pengamatan langsung kepada suatu objek yang akan diteliti, observasi dapat dilakukan dalam waktu yang singkat. Dalam hal ini, observasi bertujuan untuk mendapatkan gambaran yang tepat mengenai objek penelitian,

${ }^{71} \mathrm{Ibid}$

72Lexy. J. Moleong, Metodologi Penelitian, 157. 
sehingga dapat disusun daftar kuesinoner yang tepat atau dapat menyusun suatu desain penelitian yang cermat ${ }^{73}$.Studi dokumentasi merupakan studi yang dilakukan melalui teknik pengumpulan dokumen seperti foto, jawaban atas pertanyaan yang diajukan.Data tersebut menyngkut masalah sejarah perkembangan, perundangundangan, peraturan, kebijakan-kebijakan, program kerja, struktur kelembagaan, tata tertib dan sebagainya kemudian sumber data tersebut dilengkapi hasil wawancara dan observasi lapangan. ${ }^{74}$

\section{Analisis Data}

Analisis data merupakan proses secara sistematis untuk mengkaji dan mengumpulkan transkrip wawancara, catatan lapangan, dokumentasi dan kegiatan lain untuk memperdalam pemahaman tentang fokus penelitian.Analisis data kualitatif bersifat induktif analitik, yang menekankan pada pemaknaan kekhususan suatu kasus, bukan keumumannya (nomotetik). Menurut Miles dan Huberman, analisis data terdiri dari tiga alur kegiatan yang terjadi secara bersamaan yaitu: reduksi data, penyajian data dan penarikan kesimpulan (verifikasi).

\section{Pengecekan Keabsahan Data}

Penelitian kualitatif atau naturalistik, instrumen penelitian adalah peneliti sendiri dan kemungkinan terjadi going native atau condong keburuksangkaan (bias).Untuk menghindari terjadinya hal seperti itu, disarankan melakukan pengujian keabsahan data (credibility). ${ }^{75}$ Kredibilitas adalah upaya untuk menjamin kesalahan data dengan mengkonfirmasikan antara dua yang diperoleh dengan objek penelitian. Tujuannya adalah untuk membuktikan bahwa apa yang diamati peneliti sesuai dengan apa yang sebenarnya terjadi pada objek penelitian. ${ }^{76}$ Kriteria derajat kepercayaan akan dipenuhi melalui beberapa kegiatan: memperpanjang waktu observasi; melakukan pengamatan secara berkala; melakukan triangulasi; dan melakukan diskusi dengan teman sejawat dan pengecekan anggota (member chek).Dependabilitas merupakan kegiatan pengecekan data tentang salah-benarnya data. apabila data yang diperoleh peneliti ternyata benar, maka data tersebut tergolong data yang dependabilitas. Konfirmabilitas dalam penelitian ini dilakukan bersamaan dengan

${ }^{73}$ Ibid, 162.

${ }^{74}$ Sanusi Uwes, Manajemen Pengembangan Mutu Dosen (Jakarta: Logos Wacana Ilmu, 1999), 74.

${ }^{75}$ Lexy J. Moleong, Metodologi Penelitian Kualitatif (Bandung: Remaja Rosdakarya, 2002), 103.

${ }^{76}$ Nasution,S , Metode Penelitian Naturalistic Kualitatif (Bandung: Tarsito, 1988), 105-108 
dependabilitas ${ }^{77}$.Perbedaannya terletak pada orientasi penilaiannya.Konfirmabilitas digunakan untuk menilai hasil penelitian, sedangkan dependabilitas digunakan untuk menilai proses penelitian melalui pengumpulan data sampai ke bentuk laporan yang terstruktur dengan baik. Uji konfirmabilatas adalah tindakan terakhir dari kegiatan pengecekan keabsahan data.

\section{Paparan Data, Pembahasan, Dan Temuan}

Budaya mutu dalam perspektif mutu tidak muncul dan tumbuh dengan sendirinya, melainkan dengan sadar ditanamkan, ditumbuhkan, dipelihara, dan dipertahankan melalui suatu strategi perubahan yang kompleks yang ditentukan dan diterapkan oleh pihak madrasah. Bahwa konsep budaya di atas menunjukkan pada area manajemen kualitas proses ${ }^{78}$ yang dikemukakan oleh Mulyadi mengungkapkan bahwa Kepala Madrasah bekerjasama dengan stakeholders untuk meningkatkan kualitas, sehingga sistem yang tersirat dalam manajemen mutu tersebut mencakup komponen yang saling terkait satu sama lain yaitu konteks, input, proses, output dan outcomes.

Madrasah harus memiliki kebijakan mutu yang jelas dengan melembagakan budaya mutu sebagai bagian dari peningkatan mutu pendidikan madrasah tersebut.Dengan perspektif budaya mutu tersebut diharapkan tumbuh kemandirian madrasah, sehingga madrasah dapat mengoptimalkan sumberdaya yang tersedia untuk memajukan kualitas pendidikan dan memenuhi kebutuhan dan perkembangan peserta didik. Hal ini kepuasan pelanggan (peserta didik), sehingga Kepala Madrasah dapat menunjukkan bahwa pelanggan puas barang dan/atau jasa yang diberikan, dan Kepala Madrasah dapat menunjukkan bahwa tingkat kepuasan pelanggan terhadap madrasah yang dipimpinnya lebih tinggi dibandingkan dengan madrasah pesaingnya ${ }^{79}$

Madrasah harus melaksanakan dan mencapai sasaran mutu pendidikan melalui upaya inovatif dan kreatif dengan dukungan orangtua peserta didik, masyarakat dan pemerintah daerah, serta bertanggung jawab tentang mutu pendidikan kepada pemerintah, orangtua, masyarakat, dan stakeholders pendidikan lainya. Bagian terakhir mengenai konsep budaya mutu, khususnya di madrasah mengedepankan akhlaqul

${ }^{77}$ Ibid, 377

${ }^{78}$ Mulyadi, Kepemimpinan Kepala, 83.

${ }^{79}$ Ibid. 
karimah dalam melaksanakan segala sesuatu karena madarasah ini mencetak siswa dan siswinya memiliki ilmu umum dan ilmu agama dalam menjalankan kehidupan bermasyarakat yang sesuai dengan syariat Islam. Berarti Kepala Madrasah memiliki empat dimensi " $K$ " yaitu komitemen, kemampuan, kepaduan, dan konsistensi ${ }^{80}$.

Selain itu, konsep budaya yang dikembangkan oleh Kepala Madrasah, sebagai pendukung sebuah pandangan. Wakil Kepala Madrasah, bagian kesiswaan sangat bertanggung jawab terhadap kegiatan madrasah baik kegiatan akademik maupun non akademik. Selanjutnya, untuk menjaga mutu madrasah baik mutu akademik dan non akademik, serta akhlakul karimah madrasah memiliki ukuran.Hal ini memberikan arti budaya sebagai gabungan kompleks asumsi ${ }^{81}$ sebab sebagai wakil kepala bagian kesiswaan yang memang bertanggung jawab terhadap kegiatan non akademik, maka seluruh kegiatan non akademik diupayakan untuk menunjang/mendukung kualitas pendidikan di madrasah.Hal ini terbukti dengan prestasi-prestasi selama tahun pelajaran 2013/2014 ini.Misalnya, kegiatan desain grafis, kempo, Al Banjari, LKTI, baca dan tulis puisi, kaligrafi.

Stakeholders lain seperti wakil kepala madrasah di masing-masing urusan juga mendukung pandangan Kepala Madrasah mengenai konsep budaya mutu yang dikembangkan di madrasah ini bersifat umum dan berkesinambungan. Yang dimaksudkan dengan umum adalah kualitas yang dikembangkan itu tidak hanya kualitatif guru sebagai penyampai materi, atau siswa sebagai penerima materi, tetapi kualitas pelayanan yang terus-menerus diberikan. Misalnya, bidang parana prasarana seperti LCD proyektor, dan akses internet wifi, perpustakaan dan sebagainya. Demikian juga dengan kegiatan ekstrakurikuler yang diikuti oleh siswa, kami terus mencoba untuk terus mewadahi bakat yang dimiliki siswa, sehingga bakat itu bisa terasah dan menghasilkan prestasi.

Jadi, budaya mutu yang dikembangkan di madrasah yaitu dengan memberikan fasilitas pendukung kegiatan terutama kegiatan ekstrakurikuler. Berarti konsep budaya mutu dengan memenuhi sarana dan prasarana tersebut sesuai dengan pandangan Juran JM, yaitu peningkatan mutu dengan membangun prasarana yang diperlukan untuk penjaminan kegiatan peningkatan mutu pendidikan, membentuk tim pelaksana

80Purwanto, Budaya Perusahaan (Yogjakarta: Pustaka Pelajar, 2008), 69.

${ }^{81}$ Stoner dkk.,Manajemen(Jakarta: Prenhallingndo,1996), 57. 
kegiatan peningkatan mutu pendidikan dan sumber daya, motivasi, dan pelatihan yang dibutuhkan oleh tim untuk mendiagnosa penyebabnya, menentukan alternatif pemecahannya dan mempertahankan kondisi mutu pendidikan yang telah diraih. ${ }^{82}$. Berdasarkan paparan dan pembahasan, maka diperoleh temuan penelitian, yaitu: konsep budaya mutu yang dikembangkan merupakan kesepakatan bersama, sistem kerja seluruh komponen madrasah, pengembangan budaya mutu akhirnya membuahkan kepuasan bersama, lembaga madrasah dalam mengedepankan budaya Islami, kekuatan budaya mutu yang disepakati dapat memacu kultur yang dinginkan, dan nilai-nilai mutu akademik religius berupa akhlaq, perilaku, sikap, silahturrahim, dan nilai akademik, nilai unggul, kedisplinan, dan relewan.

\section{Catatan Akhir}

Konsep budaya mutu yang dikembangkan di madrasah disesuaikan cita-cita dan nilai-nilai mutu dalam visi misi madrasahyang ditindaklanjutidalam kebijakan serta disosialisasikan secara meluas; dijalankan dengan komitmen yang tinggi; dibiasakan menjadi budaya mutu yang dikembangkan; pengembangan budaya mutu religius diprogramkan dan dikembangkan melalui kebiasaan berperilaku dalam kehidupan sehari-hari; dan diinternalisasikan nilai-nilai budaya akademik religius secara simultan.

Adapun hasil penelitian ini juga direkomendasikan kepada lembaga pendidikan, pengelola lembaga pendidikan, guru, dan peneliti lain disarankan agar dalam melakukan penelitian sejenis memakai lokasi penelitian yang lebih luas, sampel lebih banyak dan menggunakan rancangan penelitian yang lebih kompleks seperti eksperimen, etnografi dan lainnya, menggunakan strategi yang lebih banyak lagi, juga melakukan penelitian pada tingkat pendidikan yang lebih tinggi seperti universitas, sehingga dapat ditemukan hasil yang lebih optimal dan bisa digeneralisasikan pada wilayah yang lebih luas.

82Juran J.M., Juran on Leadership for Quality (USA: Juran Institute, Inc, 1990), 23-24. 


\section{Daftar Rujukan}

Agger, Ben. 2003. Teori Sosial Kritis. Yogjakarta: Kreasi Wacana.

Aliran-aliran lain adalah neo-evolutionism, ethno-sciences, cultural ecology dan sebagainya.Dalam bahasa Inggeris dipanggil culture, Latin cultus, Jerman kultur , Itali cultura, Parsi farhang, Mandarin wenhua dan bahasa Arab althaq a fah.

Armand V, Fiegenbaum.1991. Total Quality Control, 3rd Edition.

A.R. Radcliffe-Brown .1952. Structure and Function in Primitive Society. London : Cohen \& West.

Barker, Chris. 2005. Cultural Studies : Teori dan Praktik, Terj. Bentang: Tim KUNCI Cultural Studies Centre.

Bronislaw Malinowski .1960. A Scientific Theory of Culture. New York : Oxford University Press.

Claude Lévi-Strauss .1963. Structural Anthropology.New York : Basic Books Inc.

Daniel, V. Hunt. 1993. Managing for Quality. Illinois: Businness one Irwin Homewood

Deming, W.Edward. 1986. Out of Crisis .Cambridge: Massachussets Institute of Technology.

Edward B. Tylor .1958. Primitive Culture . New York : Harper Torchbooks.

Edward, Sallis. (tanpa tahun). Total Quality Management In Education (Alih $\quad$ Bahasa:

Franz Boas .1938. The Mind of Primitive Man. (edisi semakan), New York : MacMillan

Hajah Noresah Baharom et al. (eds.) .2005. Kamus Dewan . (edisi keempat), Kuala

Lumpur : Dewan Bahasa dan Pustaka.

Haji Abdul Malik Karim Amrullah .1966. Pandangan Hidup Muslim . (cetakan kedua), Jakarta : Bulan Bintang.

Hashim Awang A.R. 1998. Budaya dan Kebudayaan : Teori, Isu dan Persoalan . Kuala Lumpur : Citra Budaya.

http://blog.umy.ac.id/wiwinsundari/2011/11/09/budaya-madrasah-school-culture/ Jerome, S. 2005. Quality in Education An Implementation Hanndbook, (Alih Bahasa: Yosal Iriantara). Yogyakarta: Pustaka Belajar, Cetakan 1.

Juran J.M. 1990. Juran on Leadership for Quality. USA: Juran Institute, Inc. 
Kujala, J.; P. Ullrank. 2004. Total Quality Management as a Cultural Phenomenon. [Online]. Tersedia: www.asq.org

Koentjaraningrat. 1990. Pengantar Antropologi . Kuala Lumpur : Pustaka Antara.

Lexy J. Moleong. 2002. Metodologi Penelitian Kualitatif .Bandung: PT. Remaja Rosdakarya.

Lipham J.M., Rankin R.E. \& Hoech J.A. 1985.The Principal Concept, Competencies and Cases.New York : Longman, Inc.

Lutfi.,Mukhtar. 1992. Konvensi Nasional Pendidikan Indonesia II,. Manajemen Sistem Pendidikan Nasional: Sentralisasi, Dekonsentrasi dan Desentralisasi. Bandung: University Press IKIP Bandung

Mulyadi.2010. Kepemimpinan Kepala Madrasah dalam Mengembangkan Budaya Mutu. Malang

Mulyasa, E.2003. Manajemen Berbasis Madrasah, Konsep, Strategi dan Implementasl .Bandung: PT Remaja Rosdakarya. Nana, Syaodih

Nasution, M.N. 2001.Manajemen Mutu Terpadu (Total Quality Manajement). Jakarta: Galia Indonesia.

Nasution, S. 1988. Metode Penelitian Naturalistic Kualitatif.Bandung: Tarsito.

Philip B. Crosby. 1979. Quality is Free . New York: New American Library.

Purwanto. 2008. Budaya Perusahaan .Yogyakarta: Pustaka Pelajar..

Purwanto, Ngalim 2002. Administrasi Dan Supervisi Pendidikan. Bandung: PT. Remaja Rosdakarya,

Ralph Linton .1968. The Cultural Background of Personality.London : Routledge \& Kegan Paul.

Robins. 1994. Teori Madrasah (Struktur, Desain \& Aplikasi). Jakarta.

Robbins, Stephen P., 2001. Organizational Behavior. New Jersey: Pearson Education International

Sanusi, Uwes. 1999. Manajemen Pengembangan Mutu Dosen .Jakarta: Logos Wacana Ilmu,

Stoner, James A. F. \& Edward Freeman, Daniel R. Gilbert, Jr. 1996. Manajemen. Edisi Indonesia, Alih Bahasa Alexander Sindoro. Jakarta: PT. Prehallindo. 
Sudarwan, Danin. 2006.Visi Baru Manajemen Madrasah .Jakarta : PT. Bumi Aksara. Suderadjat, Hari. 2005. Manajemen Peningkatan Mutu Berbasis Madrasab; Peningkatan Mutu Pendidikan Melalui Implementasi KBK, Bandung :

Suharsaputra, 2010. Administrasi Pendidikan. Bandung: PT. Refika Aditama.

Sukmadinata, Nana Syaodij. 2006. Pengendalian Mutu pendidikan Madrasah Menengah.Bandung: PT Refik Aditama.

Sutan Takdir Alisjahbana .1982. Perkembangan Sejarab Kebudayaan Indonesia Piliban dari Jurusan Nilai- nilai . (cetakan ketiga), Jakarta : PT. Dian Rakyat.

Tony Bennet. 1980. "Popular Culture : A Teaching Object, Screen Education" yang dikutip dalam buku Keith Tester, Media, Budaya dan Moralitas, terj. Muhammad Syukri, Kreasi Wacana dan Juxtapose.

Undang-undang Republik Indonesia Nomor 20 tahun 2003 Tentang Sistem Pendidikan Nasional. Yogyakarta: Pustaka Widyatama.

Umaedi. 1999. Manajemen Mutu Berbasis Madrasah. Jakarta: Direktorat Jenderal Pendidikan Dasar dan Menengah Umum.

Usman, Husaini. 2006. Manajemen Teori, Praktek Dan Riset Pendidikan, Jakarta : Bumi Aksara.

Yuki, G. 1991. Leadership in Organization. Jakarta: Prentice Hall Inc.

Yoder, Dale. 2003. Personel Principles and Policies.Second Edition . Maruzen Company Ltd: Prentice Hall Inc.

Wahjosumidjo. 1996. Kempemimpinan Kepala Madrasah.

Zainal Kling .1987. Konsep Kebudayaan Kebangsaan Malaysia (dalam Pertemuan Dunia Melayu '82) .KualaLumpur : Dewan Bahasa dan Pustaka. 